\title{
Perawatan Kuretase Gingiva Gigi Anterior pada Periodontitis: Laporan Kasus
}

\author{
Johanna A. Khoman, Miranti A. Minanga
}

Program Studi Pendidikan Dokter Gigi Fakultas Kedokteran Universitas Sam Ratulangi, Manado, Indonesia

Email: mirantipaotonan@gmail.com

\begin{abstract}
In general, periodontal disease is caused by bacterial plaque on the tooth surface. Bacterial elimination by curettage will reduce periodontal inflammation. This case report was aimed to review the immune response to chronic periodontitis as well as case management with curettage. We reported a 22-year-old female patient came to the Dental and Oral Hospital of University of Sam Ratulangi (Unsrat) with complaints of swollen front gum, frequent gum bleeding, and gum bleeding during tooth brushing. The gum bleeding had occurred since 6 months ago. Tartar cleaning was performed on her three weeks ago. Based on anamnesis, the patient did not suffer from any systemic disease. Intraoral examination revealed that there were reddish gingiva, swelling in region I, II, III, and IV, and probing depth of teeth 21-25 with a mean of 4 $\mathrm{mm}$. Oral Hygiene Index measurement obtained a value of 1.7 (medium category). This case was diagnosed as chronic periodontitis. The treatment consisted of scaling, irrigation with $\mathrm{NaCl}$ solution and aquadest, root planing, gingival curettage, and periodontal pack application. At the first control (one week after gingival curettage), the patient did not complain of any pain on the curettage area, periodontal pack was loose. The objective examination still revealed redness, debris, and calculus, OHI-S: $0,8+0,3=1,1$ (good category). The prognosis was good since the patient was cooperative, did not have any systemic disease, and had high motivation to maintain oral hygiene.
\end{abstract}

Keywords: curettage, chronic peridontitis

\begin{abstract}
Abstrak: Secara umum penyakit periodontal disebabkan oleh bakteri plak pada permukaan gigi. Eliminasi bakteri dengan kuretase akan menurunkan peradangan periodontal. Laporan kasus ini bertujuan untuk menjelaskan respon imun terhadap penyakit periodontitis kronis serta penatalaksanaan kasus dengan kuretase. Kami melaporkan kasus seorang pasien perempuan berusia 22 tahun datang ke Rumah Sakit Gigi dan Mulut Pendidikan Universitas Sam Ratulangi (Unsrat) dengan keluhan gusi bagian depan bengkak, gusi sering berdarah, dan perdarahan gusi saat menyikat gigi. Gusi berdarah sejak sekitar 6 bulan lalu dan pasien melakukan pembersihan karang gigi sekitar 3 minggu lalu. Dari hasil anamnesis didapatkan bahwa pasien tidak mempunyai riwayat penyakit sistemik. Pada pemeriksaan intraoral terdapat gingiva berwarna kemerahan dan pembengkakan di region I, II, III, IV, probing depthgigi 21-25 dengan rerata sebesar $4 \mathrm{~mm}$. Hasil pengukuran Oral Hygiene Index(OHI) ialah 1,7 (kategori sedang). Diagnosis klinis kasus ini ialah periodontitis kronis. Tindakan yang dilakukan ialah scaling, irigasi dengan $\mathrm{NaCl}$ dan akuades, root planing, kuretase gingiva, dan pemasangan periodontal pek. Kontrol pertama dilakukan satu minggu pasca kuretase gingiva, dan pada pemeriksaan subjektif pasien tidak mengeluhkan rasa nyeri di daerah yang telah dilakukan kuretase gingiva, pek periodontal sudah terbuka malam hari pasca kuretase gingiva. Pemeriksaan objektif gingiva masih kemerahan, terdapat debris dan kalkulus, OHI-S: $0,8+0,3=1,1$ (kategori baik). Prognosis baik karena pasien kooperatif, tidak memiliki riwayat penyakit sistemik, dan memiliki motivasi yang tinggi untuk menjaga kebersihan rongga mulut.
\end{abstract}

Kata kunci: kuretase; peridontitis kronis 


\section{PENDAHULUAN}

Periodontitis merupakan faktor risiko yang berperan terhadap gangguan fungsi pengunyahan dan hilangnya gigi. Kelainan ini sering dijumpai pada masyarakat. ${ }^{1}$ Perawatan periodontitis ialah dengan initial phase therapy yang terdiri dari scaling, root planing, peningkatan oral hygiene, bahkan mungkin diperlukan penyesuaian oklusal. ${ }^{2}$ Secara umum penyakit periodontal disebabkan oleh bakteri plak pada permukaan gigi. Plak berupa lapisan tipis biofilm yang berisi kumpulan mikroorganisme patogen seperti Porphyromonas gingivalis, Actinobacillus actinomycetem comitans, Prevotela intermedia, Tannerella forsythia, serta Fusobacterium nucleatum yang merupakan deposit lunak. ${ }^{1}$

Gingivitis dan poket gingiva terjadi karena rusaknya perlekatan gingiva (loss of gum attachment) dengan akar gigi yang menandakan adanya suatu periodontitis ringan. Kerusakan jaringan karena infeksi jaringan periodontal mengandung bahanbahan toksik (berasal dari bakteri maupun respon inflamasi). Bakteri secara langsung dapat merusak jaringan pejamu yang dapat menghasilkan bermacam-macam toksin (terutama protease). Respons inflamasi menyebabkan keadaan inflamasi akut yang berakibat kerusakan jaringan, dan bila terjadi secara masif dapat merusak jaringan serta menghasilkan bahan-bahan toksik prooksidatif. ${ }^{3}$ Kerusakan progresif ligamen periodontal dan tulang alveolar (alveolar bone loss) menyebabkan gigi goyah dan mudah tanggal yang menandakan suatu periodontitis yang parah.

Kebersihan mulut yang buruk ditandai adanya timbunan plak bakterial pada karang gigi subgingival berkorelasi positif dengan keparahan periodontitis. Inflamasi merupakan barisan pertama pada sistem pertahanan tubuh terhadap jejas bakterial. Neutrofil menandakan suatu respon fagosit, terutama untuk memfagositosis dan menghancurkan antigen bakterial. Neutrofil memroduksi bahan-bahan toksik pro-oksidatif seperti oksidan/radikal bebas serta enzim-enzim hidrolitik dan proteolitik yang merupakan mekanisme penghancuran bakteri. Bahan- bahan untuk membunuh bakteri ini juga dapat merusak molekul-molekul pejamu dan menyerang jaringan di sekitar daerah inflamasi. $^{3}$

Neutrofil berespons terhadap infeksi bakteri dengan menghasilkan bahan-bahan toksik prooksidatif sebagai berikut: 1) Reactive oxygen species (ROS), berupa radikal bebas dan oksidan, seperti asam hipoklorit ( $\mathrm{HOCl})$, radikal superoksid (O2-), radikal hidroksil (OH-), hidrogen, dan peroksida $\left(\mathrm{H}_{2} \mathrm{O}_{2}\right)$. Bahan yang bersifat toksik ditujukan untuk mengoksidasi molekul bakterial; 2) Fosfatase, enzim proteolitik, glukorodinase, lipase, dan arilsulfatase merupakan enzim-enzim yang berasal dari lisosom. Asam nukleat, fosfolipid, dan senyawa yang mengandung fosfat pada bakteri diserang oleh enzim fosfatase. Enzim proteolitik menghidrolisis glukoprotein bakteri seperti katepsin dan lisozim. Glukoronidase berperan untuk mencerna karbohidrat. Lipase berperan untuk mencerna lipid sedangkan arilsulfatase dapat menghancurkan senyawa aromatik yang mengandung sulfur pada bakteri; 3) Enzim matrix metalloproteinase (MMP) yang mengandung ion $\mathrm{Zn}^{+2}$ sebagai penghancur matriks ekstrasel yang tersusun atas kolagen. Mediator pro-inflamatori (IL-1 dan TNF $\alpha$ ) yang menginduksi produksi MMPs dihasilkan oleh netrofil yang merupakan hasil stimulasi bakterial. $^{3}$

Adanya poket sering menandakan suatu penyakit periodontal. Proses bertambah dalamnya sulkus gingiva merupakan suatu poket periodontal dan gambaran klinis dari penyakit periodontal. ${ }^{2}$ Kuretase tertutup dan flap kuretase merupakan prosedur untuk menanggulangi faktor-faktor etiogenik pada poket periodontal yang bertujuan menghilangkan lesi. Jaringan patogen dan debris yang berada dalam poket periodontal harus segera dihilangkan sehingga tidak meluas menjadi lebih parah, dan kuretase merupakan suatu perawatan alternatif poket periodontal. $^{2}$

Laporan kasus ini disajikan untuk menjelaskan respon imun terhadap periodontitis kronis serta penatalaksanaan kasus periodontitis kronis dengan kuretase. 


\section{LAPORAN KASUS}

Seorang pasien perempuan berusia 22 tahun datang ke Rumah Sakit Gigi dan Mulut Pendidikan Universitas Sam Ratulangi (Unsrat) dengan keluhan gusi bagian depan bengkak, sering berdarah, dan perdarahan gusi saat menyikat gigi. Gusi berdarah sudah sejak kurang lebih enam bulan lalu. Pasien melakukan pembersihan karang gigi kurang lebih 3 minggu lalu.

Berdasarkan anamnesis didapatkan bahwa pasien tidak mempunyai riwayat penyakit sistemik. Pada pemeriksaan intraoral terdapat gingiva berwarna kemerahan dan pembengkakan di regio I, II, III, IV, probing depth gigi 21-25 dengan rerata 4 mm. Hasil pengukuran Oral Hygiene Index sebesar 1,7 (kategori sedang). Diagnosis klinis kasus ini ialah periodontitis kronis. Prognosis tergolong baik karena pasien tidak memiliki riwayat penyakit sistemik, memiliki motivasi tinggi untuk menjaga kebersihan rongga mulut, dan kooperatif.

Berdasarkan hasil anamnesis dan pemeriksaan intraoral maka tindakan awal pada pasien ini ialah dilakukan skeling. Kemudian daerah yang dikerjakan terlebih dahulu diberikan anestesi lokal menggunakan teknik infiltrasi dengan cairan anastesi Pehacain (Gambar 1). Pada penghalusan akar/root planing, alat dimasukkan sejajar sumbu gigi, mata pisau menghadap permukaan akar sampai dasar poket kemudian ditarik ke arah oklusal. Hal ini dilakukan untuk membuang koloni bakteri dan jaringan sementum yang nekrotik. Tindakan ini dilakukan berulang sampai permukaan akar terasa halus, dilanjutkan dengan irigasi menggunakan larutan $\mathrm{NaCl}$ fisiologis $0,9 \%$ kemudian dengan akuades hingga bersih. Kuretase gingiva regio anterior pada gigi 23 menggunakan kuret Gracey No.1-2, 3-4, sedangkan pada gigi 24, 25 menggunakan kuret Gracey No. 5-6 (Gambar 2). Kuret dimasukkan sejajar sumbu gigi mata pisau menghadap gingiva (merupakan dinding poket kedasar poket), ditarik kearah oklusal, dan dilakukan pembuangan jaringan inflamasi dan granulasi. Hal ini dilakukan pada poket mesial dan poket distal secara bertahap. Setelah itu daerah operasi diirigasi kembali dengan larutan $\mathrm{NaCl}$ fisiologis 0,9 $\%$ dan akuades sampai bersih (Gambar 3). Pembersihan dan pengeringan daerah operasi dilakukan dengan tampon steril. Gingiva diadaptasikan ke permukaan gigi dengan cara menekan gingival kearah gigi dengan jari selama 1-3 menit.

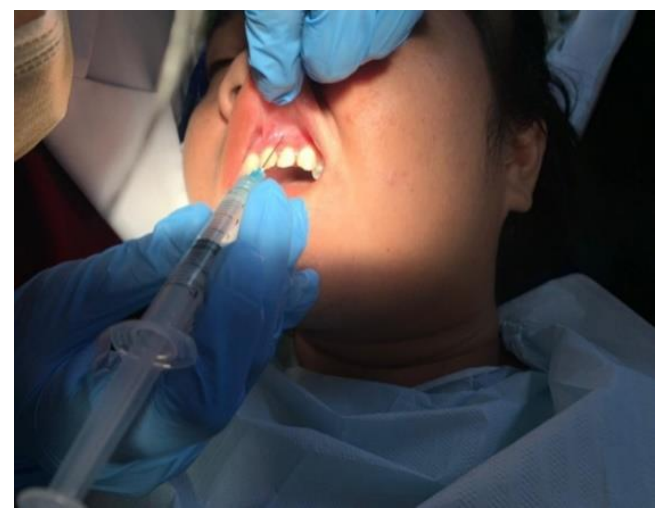

Gambar 1, Anastesi menggunakan teknik infiltrasi

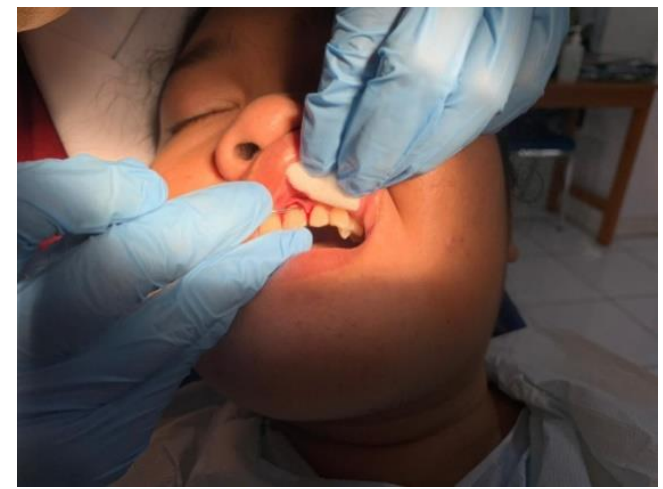

Gambar 2. Proses kuretase gingiva

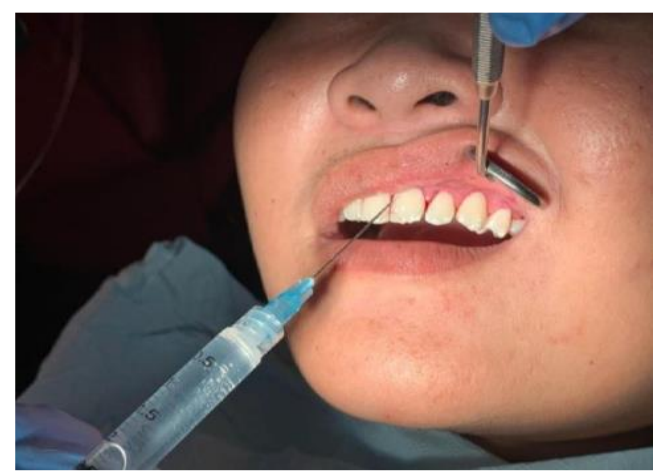

Gambar 3. Irigasi menggunakan larutan $\mathrm{NaCl}$ fisiologis $0,9 \%$ dan akuades

Periodontal pek yang dikemas dalam bentuk dua tube pasta seperti Coe-Pak ${ }^{\circledR}$ 
dipersiapkan dengan mencampur pasta basis dan pasta akselerator sama panjang, dan diaduk sampai didapatkan warna yang merata. Dalam 2-3 menit pasta yang telah diaduk sudah dapat dibentuk dan ditempatkan di atas luka. Untuk menempatkan periodontal pek, terlebih dulu dibentuk menjadi batangan sepanjang luka bedah yang hendak dibalut. Agar periodontal pek tidak melekat ke tangan, jari tangan sebaiknya diolesi vaselin, dengan terlebih dahulu mengeringkan daerah luka bedah. Setelah itu batangan periodontal pek ditempatkan pada daerah luka bedah dan ditekan sepanjang gingival dan interproksimal. Pada permukaan vestibular penekanan dapat dilakukan dengan menekan bibir atau pipi pasien sehingga pembalut tidak melekat ke jari. Periodontal pek harus membungkus sebagian gigi dan gingiva. Selain itu harus diperhatikan agar periodontal pek pada daerah gigi tidak sampai menghalangi oklusi agar tidak mudah lepas karena pecah, dan tidak meluas terlalu jauh kearah lipatan mukosa bukal agar tidak mengiritasi bila telah keras. Daerah operasi dibersihkan dan pasien diberikan instruksi pasca-kuretase dan resep amoksisilin 3x500 mg, natrium diklofenak 2x50 mg, dan vitamin B kompleks plus vitamin $\mathrm{C}$.

Kontrol pertama dilakukan satu minggu pasca kuretase gingiva. Pada pemeriksaan subjektif, pasien tidak mengeluhkan rasa nyeri di daerah yang telah dilakukan kuretase gingiva, dan pek periodontal sudah terbuka malam hari pasca kuretase gingiva. Pada pemeriksaan objektif tampak gingiva masih kemerahan, terdapat debris dan kalkulus, dan OHI-S: 0,8+0,3=1,1 (kategori baik). Penyembuhan sempurna pada luka terjadi pada tahap kontrol ketiga yaitu tiga minggu pasca kuretase.

\section{BAHASAN}

Periodontitis disebabkan oleh bakteri yang merupakan penyakit infeksi pada jaringan penyanggah gigi. Periodontitis juga menyebabkan kerusakan tulang alveolar dan ligamen periodontal sehingga membentuk poket, menyebabkan resesi, atau keduanya. ${ }^{4}$ Penyakit periodontal sendiri memiliki etio- logi dan patogenesis yang multifaktorial; adanya bakteri patogen yang berperan tidak cukup menyebabkan terjadinya kelainan. ${ }^{5}$

Periodontitis kronis disebabkan oleh bakteri Gram negatif, bakteri anaerob, dan bakteri mikroaerofilik yang terdapat pada daerah subgingival dan memicu prostaglandin pro-inflamasi serta sitokin yang mengakibatkan terjadinya kerusakan jaringan periodontal. ${ }^{6}$ Bakteri patogen penyebab terjadinya penyakit periodontal seperti Aggregatibacter actinomycetemcomitans Treponema denticola, dan Tannerella forythia dapat mengakibatkan terjadinya inflamasi pada jaringan periodontal. ${ }^{7,8}$

Respon imun dan inflamasi berperan penting dalam perkembangan penyakit periodontal namun dapat bersifat merusak jaringan, dan juga dipengaruhi oleh lingkungan, faktor genetik penderita, dan pola hidup. ${ }^{9}$ Sistem imun bertujuan melindungi integritas dan individu serta mencegah invasi organisme dan zat berbahaya di lingkungan yang dapat merusak dirinya yang merupakan suatu sistem koordinasi respons biologi. ${ }^{10}$

Leukosit berperan penting terhadap respons peradangan. Terhadap setiap bahan infeksius yang mungkin ada, leukosit menyediakan pertahanan yang kuat dan cepat. Pada infeksi yang disebabkan bakteri maupun mikroba lain yang infeksius dan toksik, dapat dijumpai peningkatan leukosit. Pada radang akut leukosit yang berperan yaitu neutrofil dan monosit, sedangkan pada radang kronik yang berperan yaitu makrofag dan limfosit. ${ }^{11}$

Keberadaan makrofag dan neutrofil saling berhubungan dalam proses penyembuhan luka. Neutrofil merupakan pertahanan seluler pertama yang jumlahnya meningkat pada awal pasca perlukaan. Makrofag juga aktif melepaskan berbagai macam growth factor (TGF- $\beta$ ), PDGF komplemen plasma aktif C3a dan C5a yang dibutuhkan dalam proses penyembuhan luka. ${ }^{12}$

Mekanisme terjadinya pertahanan tubuh untuk melawan bakteri pada plak gigi dan yang terdapat pada taut epitel (epithelium junctional) dan sulkus gingiva ialah ketika neutrofil mengeluarkan enzim lisosom mela- 
lui degranulasi seperti lisozim, elastase, kolagenase, mieloperoksidase selama terjadinya fagositosis atau setelah nekrosis sehingga menyebabkan kerusakan jaringan sekitar. ${ }^{13}$

Kasus ini ialah suatu periodontitis kronis dengan rerata kedalaman poket 4 mm, keadaan jaringan terinflamasi, non fibrotik, edematous, dan kontur gingiva membulat. Penanganan yang dilakukan ialah perawatan kuretase yang bertujuan untuk mengurangi dan menghilangkan terjadinya poket periodontal serta memperbaiki perlekatan dan merangsang terbentuknya perlekatan baru. ${ }^{14}$ Prosedur perawatan kuretase dilakukan menggunakan kuret Gracey untuk gigi posterior. Bagian yang tajam dari kuret Gracey diarahkan pada daerah epitel sulkuler kemudian dilakukan pengerokan sepanjang jaringan lunak sehingga jaringan granulasi seperti fibroblastik dan proliferasi angioblastik, serta kalkulus yang berisi akumulasi bakteri dapat terangkat. $^{2}$

Setelah dilakukan perawatan kuretase akan terjadi proses perbaikan epitel sulkuler yang berlangsung antara dua sampai tujuh hari, sedangkan untuk perbaikan epitel cekat terjadi selama lima hari. Pengerutan margin gingiva terjadi setelah satu minggu dan penyembuhan sempurna terjadi antara dua sampai tiga minggu setelah kuretase. Penyembuhan tersebut dipengaruhi oleh beberapa faktor seperti faktor sistemik, sistem kekebalan tubuh pasien, dan kepedulian pasien untuk menjaga kebersihan rongga mulutnya. ${ }^{14}$ Pada kasus ini proses perbaikan epitel sulkuler dan epitel cekat sudah mulai nampak pada kontrol pertama (satu minggu pasca kuretase). Penyembuhan sempurna pada luka terjadi pada tahap kontrol ketiga yaitu tiga minggu pasca kuretase. Antibiotik amoksisilin 3x500 mg didapatkan masih efektif pada kasus ini yang sejalan dengan yang dilaporkan oleh Bhat et al dan Khumar et al. ${ }^{15,16}$

\section{SIMPULAN}

Penyakit periodontal memiliki etiologi dan patogenesis yang multifaktorial. Pada radang akut leukosit yang berperan yaitu neutrofil dan monosit, sedangkan pada radang kronik yang berperan yaitu makrofag dan limfosit. Penanganan periodontitis kronis dengan melakukan perawatan kuretase bertujuan untuk mengurangi dan menghilangkan terjadinya poket periodontal serta memperbaiki perlekatan dan merangsang terbentuknya perlekatan baru.

Pada kasus ini, tindakan yang dilakukan telah sesuai dengan panduan perawatan periodontitis kronis yaitu scaling, irigasi dengan $\mathrm{NaCl}$ dan akuades, root planing, kuretase gingiva, dan pemasangan periodontal pek. Prognosis kasus ini baik karena pasien kooperatif, tidak memiliki riwayat penyakit sistemik, dan memiliki motivasi yang tinggi untuk menjaga kebersihan rongga mulut.

\section{Konflik Kepentingan}

Penulis menyatakan tidak terdapat konflik kepentingan dalam studi ini.

\section{DAFTAR PUSTAKA}

1. Ermawati T. Periodontitis dan diabetes melitus. Stomatognatic.2012;9(3):152-4.

2. Dinyati M, Andi MA. Kuretase gingiva sebagai perawatan poket periodontal. Makassar Dent J. 2016;5(2):58-64.

3. Susilawati IDA. Periodontal infection is a "silent killer". Stomatognatic. 2011; 8(1):21-6.

4. Carranza FA. Clinical Periodontology (9th ed). Philadelphia: WB Saunders, 2006; p. 160-83, 349-50.

5. Kuswandani OS. Academic stress influences periodontal health condition and interleukin-1 beta level. Journal of Dentistry Indonesia (JDI), 2014;21(1):16-20.

6. Armitage GC. Periodontal diagnoses and classification of periodontal diseases. Periodontology. 2000;34:9-21.

7. Gumus P. The role of TLRs in the patho-genesis of periodontal diseases. Journal of Dental Science and Therapy (JDST). 2016;1(1):3-6.

8. Hajishengallis G, John DL. Microbial manipulation of receptor crosstalk in innate immunity. Nat Rev Immunol. 2011; 11(3):187-200.

9. Ekaputri S, Masulili SLC. Cairan sulkus gingiva sebagai indikator keadaan jaringan periodontal. Maj Ked Gigi Indones. 
2010;17(1):81-6.

10. Munasir Z. Respons imun terhadap infeksi bakteri. Sari Pediatri, 2001;2(4):193-7.

11. Nuarita R, Praharani D, Kusumawardani B. Pengaruh penyakit periodontal selama masa kehamilan terhadap jumlah total leukosit dan hitung jenis leukosit. Stomatognatic, 2012;9(3):125-30.

12. Kumar V, Cotran RS, Robbin SL. Buku Ajar Patologi Volume 1 (7th ed). Jakarta: EGC, 2007; p. 45-7.

13. Kornman KS. Mapping the pathogenesis of periodontitis: a new look. J Periodontol. 2008;79(8):1560-8.

14. Witjaksono W, Roselinda A, Kannan TP.
Clinical evaluation in periodontitis patient after currettage. Dent J. 2006; 39(3):102-6.

15. Bhat Muzafar A, Amin SS, Bhat Mudasir A, Huda. Effects of amoxicillin - metronidazole combination versus ciprofloxacin as an adjunct to nonsurgical periodontal therapy of chronic generalized periodontitis. International Journal of Contemporary Medical Research (IJCMR). 2018;5(9):116-9.

16. Kapoor A, Malhotra R, Grover V, Grover D. Systemic antibiotic therapy in periodontics. Dent Res J (Isfahan). 2012;9(5): 505-15. 